\title{
Increased grazing rates of microplankton in response to small-scale turbulence
}

\author{
Francesc Peters ${ }^{1, *}$, Tom Gross ${ }^{2}$ \\ ${ }^{1}$ Institute of Ecology, University of Georgia, Athens, Georgia 30602-2202, USA \\ ${ }^{2}$ Skidaway Institute of Oceanography, 10 Ocean Science Circle, Savannah, Georgia 31411, USA
}

\begin{abstract}
Grazing rates of free-living microplanktonic organisms on bacteria-sized particles, as measured by the decrease of tracer particles over time, increased in response to small-scale turbulence. This was observed in the field, with the natural community, and in the laboratory, with a model protozoan. When ingestion rates were measured at the beginning of laboratory incubations, no statistical difference between treatments was found. Protozoan concentrations increased faster in the turbulence treatment but their cell sizes decreased compared to the non-turbulence treatment. Since direct ingestion rates were not affected by turbulence, the mechanism to explain the difference in tracer decrease remains unresolved. A complex picture of physiological and possibly behavioral changes in the protozoa owing to small-scale turbulence emerged from this study. Some of these changes have been observed before with copepods and might represent a common trend in free-living planktonic organisms. Turbulence could be an important factor in the control of bacterial populations in aquatic systems by means of increasing protozoan grazing rates
\end{abstract}

KEY WORDS: Protozoan grazing S Small-scale turbulence B Bacteria - Natural community Paraphysomonas imperforata. Ingestion rates

\section{INTRODUCTION}

In aquatic environments, the bulk of metabolic activity is carried out by organisms smaller than $100 \mu \mathrm{m}$. Microorganisms, for instance, dominate respiration rates (Williams 1984). Yet, after 20 yr of microbial food web research there is still uncertainty about the mechanisms of trophic interaction of the different microbial components of the community (Azam \& Smith 1991). Bacterial concentrations vary little in the ocean despite large variations in temperature, nutrients and carbon availability and population turnover times ranging from ca 1 to $30 \mathrm{~d}$. This constancy implies that strong regulatory mechanisms are acting on bacterial populations. Prime candidates as regulators are small protozoa (bacterivorous microflagellates) and viruses, both of which seem to be ubiquitously distributed. Viruses in the ocean have been intensely studied during the past $5 \mathrm{yr}$, but their impact on bacterial populations remains uncertain because of

\footnotetext{
- Present address: Institut de Ciènces del Mar, Passeig Joan de Borbó s/n, E-08039 Barcelona, Spain
}

the difficulty in measuring viral infection rates, lag phases and virion burst sizes (Bergh et al. 1989, Proctor \& Fuhrman 1990, Choi 1994). This work is not concerned with viruses but with microflagellate grazing.

Microflagellates are the main grazers of bacteria in aquatic environments (Fenchel 1986). Physiologically, grazing rates are affected primarily by bacterial concentration (Fenchel 1982) and temperature (Caron et al. 1986, Choi \& Peters 1992). However, bacterial concentrations are fairly constant in the ocean, and temperature alone does not seem a good predictor for grazing rates (Peters 1994b). Additionally, prey quality variables, both geometrical and nutritional, seem to play a role in food selectivity in protozoa (Verity 1991), but their effect on grazing rates remains controversial (Gonzalez et al. 1990, Monger \& Landry 1992). It is crucial to understand what physical, chemical and biological characteristics affect protozoan grazing rates. Small-scale turbulence has been proposed as a factor affecting ingestion rates in protozoa, an idea that has been recently derived from research with zooplankton (Peters 1994a, Shimeta et al. 1994). 
Planktonic organisms that feed on particulate organic matter have to encounter their prey items before ingestion can occur. The encounter probability between a predator and its prey is a function of prey concentration and prey and predator swimming velocity (Gerritsen \& Strickler 1977). Uncorrelated water velocity fluctuations characteristic of small-scale turbulence can increase the velocity of planktonic organisms above their swimming speed, with a random direction and a magnitude dependent on the intensity of turbulence. Hence, encounter probabilities are increased (Rothschild \& Osborn 1988). Recently, this effect has been demonstrated in a number of empirical studies (Marrasé et al. 1990, Sundby \& Fossum 1990, Saiz et al. 1992) for organisms as small as $1 \mathrm{~mm}$. Provided that higher encounter rates are translated into higher ingestion rates, predators can survive at a lower ambient concentration of prey in the presence of turbulence because high encounter rates are maintained. Alternatively, predators have to spend less energy in the active search process resulting in changes in growth efficiencies.

Motility is an important variable in all models that predict encounter rates of protozoa that directly intercept prey particles (Monger \& Landry 1990, Shimeta 1993). It was calculated that motility usually represents less than $1 \%$ of the energy expenditure of protozoa during balanced growth (Fenchel 1987). Based on this reasoning, one wouldn't expect growth efficiencies to change much, even if turbulence increased encounter rates. However, in nature, balanced growth seems to be the exception rather than the rule (Fenchel 1987), and a complete understanding of growth efficiency is lacking.

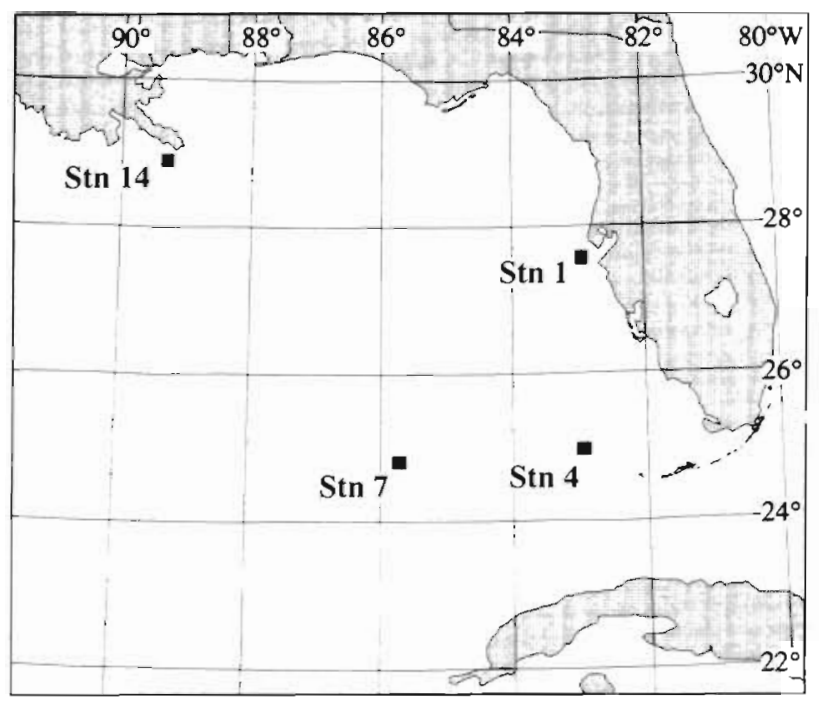

Fig. 1. Gulf of Mexico, indicating stations at which microplankton feeding experiments were done, June 1993, RV 'Pelican' Stn 1. Florida Shelf, off Tampa Bay; Stn 4: Outer Florida Shelf; Stn 7: Central Gulf of Mexico, off Campeche Bank; Stn 14: Mississippi River Plume
The effects of turbulence on protozoan feeding are starting to be addressed experimentally (Peters 1994a, Shimeta et al. 1994). At the energy levels normally found in the upper ocean, eddy motion does not occur below the Kolmogorov microscale of $\sim 0.5 \mathrm{~mm}$. The theoretical argument is that organisms smaller in size (such as most protozoa) will only experience a laminar flow field, and thus cannot be affected by uncorrelated velocity fluctuations. However, the smallest eddies are continuously being dissipated with laminar shear and replaced by others being transferred down from larger sizes. Thus, the laminar flow field experienced by the protozoa is being changed in space and time in a random fashion. Shimeta (1993) pointed out that below the Kolmogorov minimum size scale, the laminar shear field can increase contact rates between predators and their prey, although these ideas remain largely untested. The objective of this study is to experimentally determine whether protozoan feeding rates are affected by turbulence.

\section{METHODS}

Protozoan feeding experiments. A total of 5 feeding experiments were conducted, 4 with the natural microplankton community, on board the RV 'Pelican' at a series of stations in the Gulf of Mexico (Fig. 1, Table 1), and a fifth in the laboratory using a strain of the chrysomonad microflagellate Paraphysomonas imperforata isolated from the Arctic Ocean (Choi \& Peters 1992). Each experiment consisted of 6 experimental units ( 1 l glass beakers): 3 units were subjected to turbulence and the other 3 served as references. Protozoan feeding was assessed by the ingestion into food vacuoles of fluorescently labeled bacteria (FLB) as prey surrogate particles and/or by the disappearance of FLB from solution over time.

For the field study, FLB were prepared from an Escherichia coli strain that produces minicells of ca 0.4 to $0.7 \mu \mathrm{m}$ in diameter. The procedure used to obtain minicells has been described (Pace et al. 1990). For the laboratory study, T1, a Vibrio-like marine isolate of ca $0.7 \times 1.5 \mu \mathrm{m}$, served as the sole prey for Paraphysomonas imperforata. FLB were prepared from this strain. T1 was grown in $0.2 \mu \mathrm{m}$ filtered sea water amended with $0.1 \%$ yeast extract (Difco Laboratories, Detroit, MI, USA) to late exponential phase. Cells were then harvested by centrifugation $(2500 \times g$ for $10 \mathrm{~min})$ and the pellet resuspended in $0.2 \mu \mathrm{m}$ filtered sterile sea water. The centrifugation was repeated twice to wash the cells. Final resuspensions of both minicells and T1 cells were in $100 \mathrm{ml}$. The cells were stained with $2 \mathrm{mg} \mathrm{ml}^{-1}$ of 5-(4,6-dichlorotriazin-2-yl) aminofluorescein (DTAF) at $60^{\circ} \mathrm{C}$ for $2.5 \mathrm{~h}$ following the tech- 
Table 1. Physical and chemical characteristics of the sampling sites in the Gulf of Mexico during June 1993. Data were continuouly recorded on board with MIDAS (an automated system developed by the Louisiana University Marine Consortium). Both wind speed and wind direction are corrected for the ship's speed over ground, the course over ground and the heading. All parameters, with the exception of position and water temperature at sampling, are averages of data recorded for $1 \mathrm{~h}$ before arriving to station and for $1 \mathrm{~h}$ after leaving station. Less data were used at Stn 14 when crossing the Mississippi River plume. On-station data (normally $0.5 \mathrm{~h}$ ) were not used to prevent a possible influence of the ship on the different parameters. Coefficients of variation were below $5 \%$ with the exception of wind speed and wind direction (maximum of $38 \%$ ). Ambient energy dissipation rate $(\varepsilon)$ was calculated using an empirical equation that takes into account wind speed and sampling depth (Eq. 6 in MacKenzie \& Leggett 1993)

\begin{tabular}{|c|c|c|c|c|}
\hline Parameter & $\begin{array}{l}\text { Stn } 1 \\
\text { Florida Shelf }\end{array}$ & $\begin{array}{l}\operatorname{Stn} 4 \\
\text { Outer Florida Shelf }\end{array}$ & $\begin{array}{c}\text { Stn } 7 \\
\text { Central Gulf }\end{array}$ & $\begin{array}{c}\text { Stn } 14 \\
\text { Mississippi } \\
\text { River Plume }\end{array}$ \\
\hline Position & $27^{\circ} 23^{\prime} \mathrm{N}, 82^{\circ} 55^{\prime} \mathrm{W}$ & $24^{\circ} 59^{\prime} \mathrm{N}, 83^{\circ} 02^{\prime} \mathrm{W}$ & $24^{\circ} 48^{\prime} \mathrm{N}, 85^{\circ} 47^{\prime} \mathrm{W}$ & $28^{\circ} 43^{\prime} \mathrm{N}, 89^{\circ} 27^{\prime} \mathrm{W}$ \\
\hline Sampling depth $(\mathrm{m})$ & 4 & 6 & 10 & 1 \\
\hline Water temperature at sampling $\left({ }^{\circ} \mathrm{C}\right)$ & 29.3 & 28.4 & 28.6 & 28.6 \\
\hline Water temperature $\left({ }^{\circ} \mathrm{C}\right)$ & 29.4 & 28.3 & 28.6 & 28.2 \\
\hline Salinity $(\%)$ & 35.0 & 36.3 & 36.2 & 14.6 \\
\hline Chlorophyll fluorescence (volts) & 0.45 & 0.39 & 1.32 & 1.39 \\
\hline Air temperature $\left({ }^{\circ} \mathrm{C}\right)$ & 28.8 & 27.7 & 27.7 & 27.3 \\
\hline Wind speed $\left(\mathrm{m} \mathrm{s}^{-1}\right)$ & 4.1 & 5.0 & 7.8 & 4.1 \\
\hline Wind direction (degrees) & 216 & 102 & 80 & 143 \\
\hline Ambient $\varepsilon\left(\mathrm{cm}^{2} \mathrm{~s}^{-3}\right)$ & $1.1 \times 10^{-3}$ & $1.1 \times 10^{-3}$ & $1.8 \times 10^{-3}$ & $6.9 \times 10^{-3}$ \\
\hline
\end{tabular}

nique developed by Sherr et al. (1987). Then the cells were pelleted $(6000 \times g$ for $20 \mathrm{~min}$ for minicells and $2000 \times g$ for $10 \mathrm{~min}$ for $\mathrm{T} 1$ cells), the pellet resuspended and the procedure repeated to wash out excess stain. Finally, $1 \mathrm{ml}$ concentrated aliquots were frozen at $-20^{\circ} \mathrm{C}$ for later use

Before use, FLB aliquots were thawed to experimental temperature and resuspended in $10 \mathrm{ml}$ of $0.2 \mu \mathrm{m}$ filtered and sterilized water. FLB from T1 were sonicated to disrupt cell clumping while FLB from minicells did not present appreciable clumping. Several controls were run to ensure that the FLB tracer particles were stable over the experimental period, and that the stability was not affected by the turbulence treatment. This was done by counting FLB over time, either suspended in $0.2 \mu \mathrm{m}$ filtered sterile sea water or in $2 \%$ formalin fixed experimental controls. Additionally, it was ascertained that the FLB were uniformly distributed under both experimental treatments (turbulence and non-turbulence). After $24 \mathrm{~h}$, the vessels were sampled before and after thoroughly homogenizing the fluid in them, and FLB counts in both samples compared.

In the Gulf of Mexico, sea water was collected using a $10 \mathrm{l}$ Niskin bottle and screened through a $200 \mu \mathrm{m}$ Nitex net to exclude mesozooplankton. Beakers were filled to $800 \mathrm{ml}$, left to acclimate to the experimental conditions for ca $20 \mathrm{~min}$, and then minicell FLB were added at a concentration estimated to be 10 to $20 \%$ of the natural bacterial concentration. Incubation temperature was maintained within $1^{\circ} \mathrm{C}$ of sampling temperature with a customized circulating water bath. Samples $(20 \mathrm{ml}$ ) were taken at time 0 (addition of FLB) and after
12 and 18 to $24 \mathrm{~h}$, and fixed with ice-cold glutaraldehyde ( $1 \%$ final concentration). Samples were stored in the dark at $4{ }^{\circ} \mathrm{C}$ during transport to the laboratory. In the laboratory, 2 to $10 \mathrm{ml}$ subsamples were stained with 4,6-diamidino-2-phenylindole (DAPI) and filtered onto $0.2 \mu \mathrm{m}$ black polycarbonate filters (Poretics Inc.), and the filters mounted on microscope slides. FLB and natural bacteria (DAPI stained) were then enumerated separately using different filters in an epifluorescence microscope (Olympus BH-2 at $1250 \times$ magnification).

For the laboratory experiment Paraphysomonas imperforata was grown on $\mathrm{T} 1$ at $10^{\circ} \mathrm{C}$. The experiment was done at $10^{\circ} \mathrm{C}$ in a walk-in controlled-temperature cold room, with bacterial and protozoan starting concentrations of ca $10^{7}$ and $10^{3} \mathrm{ml}^{-1}$ respectively. FLB were added to the experimental vessels at about $20 \%$ the concentration of live bacteria. Samples were taken at the starting point and after 10,20,30, 45 and $60 \mathrm{~min}$, and 24 and $48 \mathrm{~h}$. Samples were fixed and stained with DAPI as before and filtered onto black polycarbonate filters $(0.2 \mu \mathrm{m}$ for free bacteria enumeration and $2 \mu \mathrm{m}$ for enumeration of FLB inside flagellate vacuoles). Flagellates (150 to 200 per sample) were scanned at each time point for FLB inside their food vacuoles. About 50 cells were sized with an ocular micrometer at a magnification of $1250 \times$. A Palmer counting chamber $(0.1 \mathrm{ml})$ was scanned at a magnification of $250 \times$ to estimate flagellate concentration.

Calculation of grazing rates. Instantaneous ingestion rates were obtained from slopes of least squares regression lines on the linear portion of plots of FLB flagellate ${ }^{-1}$ vs time. All plots showed a linear portion 
lasting for 20 to 30 min after which time vacuole saturation and turnover started to introduce non-linearity.

From the decrease of FLB over time one can calculate specific grazing rates as

$$
g=-\frac{1}{t}\left(\ln \frac{F_{t}}{F_{0}}\right)
$$

where $F_{t}$ and $F_{0}$ are the concentrations of FLB at times $t$ and 0 respectively. The assumptions are that FLB follow an exponential decrease over time and that there is no preferential feeding between natural bacteria and tracer particles. It is also assumed that natural bacteria are growing exponentially with a specific growth rate $\mu\left(d^{-1}\right)$. Then their apparent evolution over time will also follow an exponential with a specific rate a $\left(\mathrm{d}^{-1}\right)=\mu-g$. To calculate this rate:

$$
a=\frac{1}{t}\left(\ln \frac{N_{t}}{N_{0}}\right)
$$

where $N_{t}$ and $N_{0}$ are the concentrations of natural bacteria at times $t$ and 0 respectively. The number of natural bacteria consumed per unit volume over a period of time $t$ is calculated as:

$$
G=\frac{g}{a}\left(N_{t}-N_{0}\right)
$$

and the total number of bacteria per unit volume in that time as:

$$
T G=F_{0}-F_{t}+G
$$

These equations were developed by Marrasé et al. (1992) and a thorough discussion of their derivation, use and assumptions is found in Salat \& Marrasé (1994).

Turbulence generation and quantification. Turbulence was generated with vertically oscillating grids $(31.7 \mathrm{rpm})$. The grids were $9.2 \mathrm{~cm}$ in diameter and were inserted into beakers of $10 \mathrm{~cm}$ i.d. The grids were formed by $1 \mathrm{~mm}$ bars in a rhomboidal mesh pattern of $0.9 \times 0.6 \mathrm{~cm}$ (measured from center to center) giving a solidity of $21 \%$. Grids were attached to stainless steel rods ( $3 \mathrm{~mm}$ in diameter) connected by universal joints to a pulley powered by a variable speed DC gear motor (torque $12 \mathrm{lb}$-in, $\approx 1.4 \mathrm{~N} \mathrm{~m}$ ). The amplitude of oscillation was $8.5 \mathrm{~cm}$, while the water depth in the beaker was $10 \mathrm{~cm}$. This assured a homogeneity of conditions in the experimental vessels that could not be achieved by other widely used methods such as small amplitude oscillating grids at the bottom of the beaker.

We measured particle velocities with a 2-axis laser Doppler anemometer. Since the slight irregularities and curvature of the glass in the experimental beakers can interfere with the laser beams, a replicate of the same dimensions was built of acrylic plastic and enclosed in a square acrylic plastic tank filled with water; this outer sheath of water reduced the refraction of the laser beams due to the cylinder curvature. The cylinder was filled with water and spiked with rutile particles (2 to $3 \mu \mathrm{m})$. Horizontal $(u)$ and vertical (v) components of particle velocity were sampled at a rate of $100 \mathrm{~Hz}$ for $60 \mathrm{~s}$.

The experimental setup did not allow a calculation of turbulent kinetic energy dissipation rates $(\varepsilon)$ using the power spectrum, since there was no mean velocity to convert the frequency axis into a wavenumber axis. Also, the homogeneity in the beaker deterred the use of the technique developed by Marrasé et al. (1990) using vertical turbulent diffusion. The oscillation of the grid gave a clear peak signature to the velocity time series at a point in space. The $v$ time series was split into individual oscillation periods, that were then aligned mathematically using the peak signatures. The corresponding $u$ time series was split and aligned at the same points as $v$. Velocities were then ensemble averaged to give an estimate of standard deviation as a function of time within a grid oscillation. Assuming that the third component of velocity behaves exactly as the $u$ component, we calculated $q$ (the turbulent kinetic energy) over a grid oscillation according to the equation:

$$
q_{t}=1 / 2\left[2\left(\sigma_{u_{t}}\right)^{2}+\left(\sigma_{v_{t}}\right)^{2}\right]
$$

where $\sigma_{u}$ and $\sigma_{v_{1}}$ denote the standard deviations of particle velocities measured at a specific time $t$ of a grid oscillation. $\varepsilon$ was estimated from the decay of $q$ over time after the onset of a peak. This rate was not constant over a grid oscillation but followed a negative log-log relationship, with transient high values just after the peak and decreasingly smaller values until the next peak caused by passage of the grid (Fig. 2).

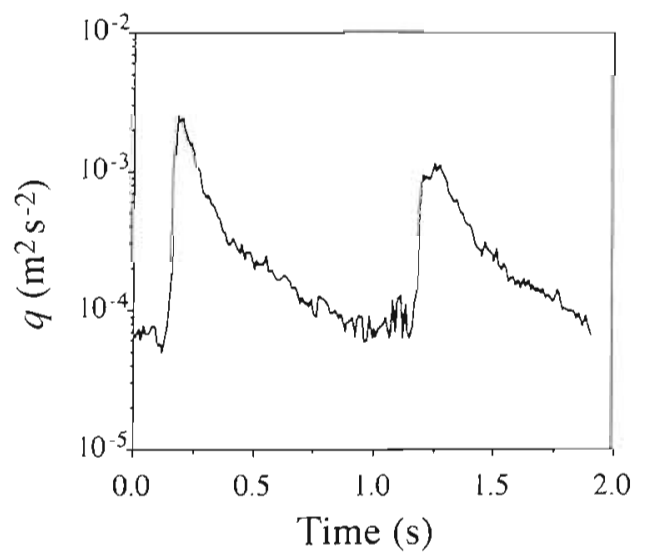

Fig. 2. Turbulent kinetic energy $(q)$ as a function of time during one grid oscillation. The oscillation period is $1.89 \mathrm{~s}$. The measurement was taken $2 \mathrm{~cm}$ off center at a height of $5 \mathrm{~cm}$ from the bottom. The first peak corresponds to the passage of the grid moving down in the beaker and the second to the passage of the grid coming up again 
Energy dissipation rates for the center of the beaker ranged from $0.85 \mathrm{~cm}^{2} \mathrm{~s}^{-3}$ to $8.6 \times 10^{3} \mathrm{~cm}^{2} \mathrm{~s}^{-3}$ at the energy peak. Slightly smaller values, but within the same order of magnitude, were measured away from the beaker center in all 3 directions. Dissipation rate averaged $14.5 \mathrm{~cm}^{2} \mathrm{~s}^{-3}$. The measurements made at different locations about the volume showed that turbulence was quasi homogeneous and isotropic, i.e. turbulence was quite even throughout the entire water volume. At these small scales, turbulence in the ocean has the same characteristics (Tennekes \& Lumley 1972).

An average $\varepsilon$ was also theoretically estimated from the hydrodynamic drag force $\left(F_{d}\right)$ exerted on the grid in 1 oscillation.

$$
F_{d}(t)=C d \rho_{w} a V(t)
$$

where $C d$ is the drag coefficient estimated to be $0.7, \rho_{w}$ is the density of water, $a$ is the solid area of the grid and $V(t)$ the time dependent vertical velocity of the grid given by

$$
V(t)=V_{\max } \sin (\omega t)
$$

where $\omega$ is the frequency of oscillation. Then the energy put into the system in 1 oscillation is:

$$
E=4 \int_{0}^{T / 4} F_{d}(t) V(t) \mathrm{d} t
$$

where $T$ is the oscillation period. Assuming that all this energy is put into eddy turbulence, the average dissipation rate is

$$
\varepsilon=\frac{E}{T \text { vol }}
$$

where vol is the volume of water in the beaker. A value of $12 \mathrm{~cm}^{2} \mathrm{~s}^{-3}$ was obtained. This estimate compares well with the average $\varepsilon$ measured with the laser Doppler anemometer.

\section{RESULTS}

The controls showed that there was no significant breakdown of FLB in $0.2 \mu \mathrm{m}$ filtered sterile sea water over a $24 \mathrm{~h}$ period $(\mathrm{p}=0.326)$. The FLB concentrations remained unchanged in both experimental treatments (turbulence and non-turbulence), and moreover, FLB were homogeneously distributed in the experimental vessels. In a $2 \%$ formalin fixed control of the lab experiment, there was no significant decline of FLB ( $p=$ 0.694 ) or bacteria ( $p=0.673$ ) after $48 \mathrm{~h}$.

In 3 out of 4 experiments in the Gulf of Mexico, FLB were removed from sea water faster in the presence of turbulence $(p<0.05)$. In one case (Stn 1) the concentration of FLB at the end of the incubation was not significantly different $(p=0.371)$ between the treatments (Fig. 3). The decrease of tracer over time tended to be
Fig. 3. Particle concentration evolution for the grazing experiments in the Gulf of Mexico. Symbols are means ( $\pm 1 \mathrm{SE}$ ) of 3 replicates. Where error bars cannot be seen, they are contained within the symbol. Filled symbols: DAPI-stained bacteria; open symbols: FLB. Broken lines: turbulence treatment; solid lines: non-turbulence treatment
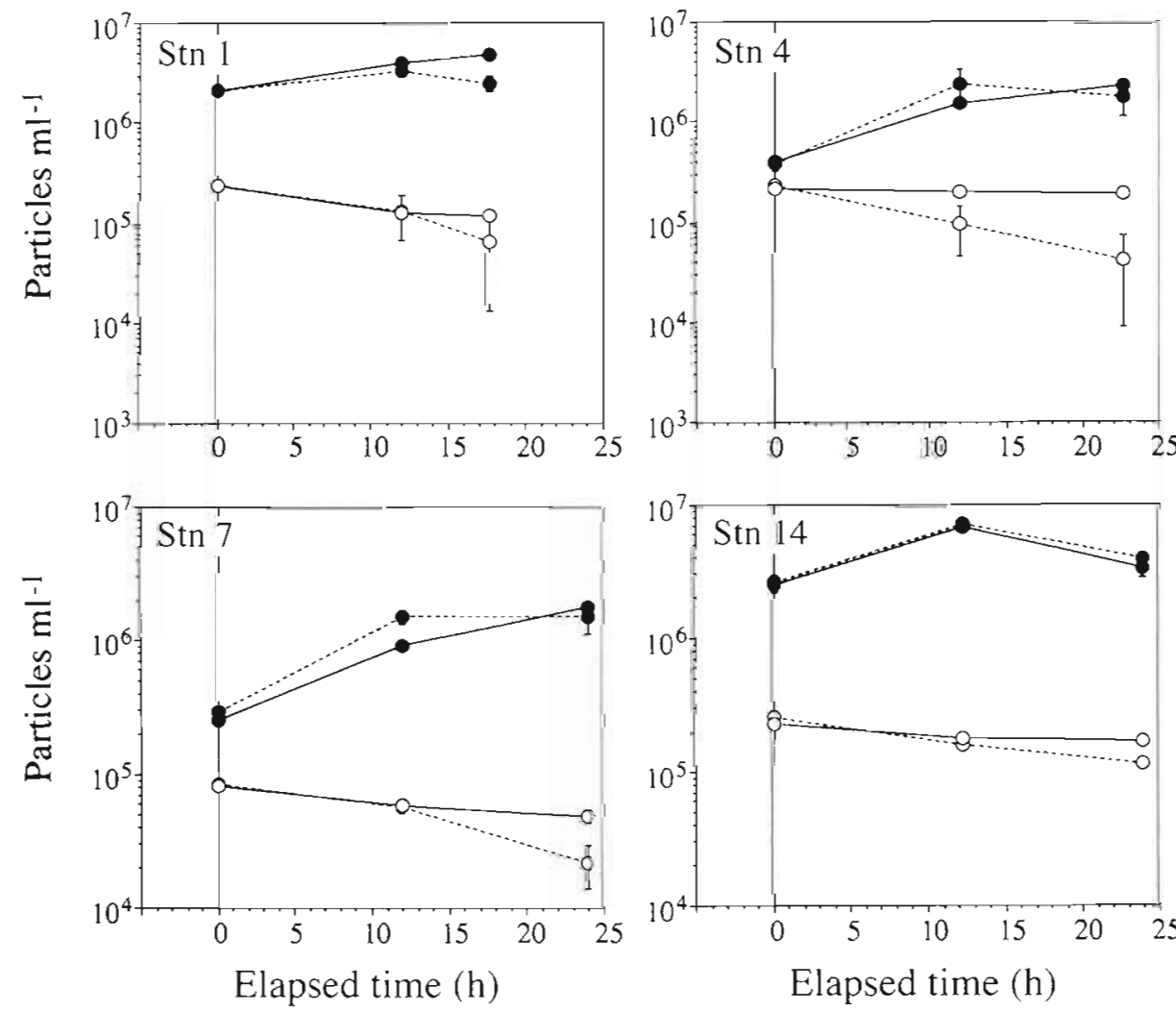
Table 2. Specific grazing rates $\left(g\right.$, in $\left.d^{-1}\right)$, specific bacterial growth rates $\left(a\right.$, in $\mathrm{d}^{-1}$ ) and total bacteria consumed ( $T G$, in bacteria consumed $\mathrm{ml}^{-1}$ in a given period), in the turbulence (Tur.) and non-turbulence (Non-tur.) treatments, calculated from averaged data using equations of Marrasé el al. (1993). Subindices indicate whether the parameter is calculated for the first $12 \mathrm{~h} \mathrm{(0-1)}$ or from $12 \mathrm{~h}$ to the end of the experiment (1-2). For the lab experiment $(0-1)$ is calculated for the first $24 \mathrm{~h}$ and $(1-2)$ from 24 to $48 \mathrm{~h}$. Total $T G$ is calculated by adding $T G_{(0-1)}$ and $T G_{12-2)}$. Ratio: total $T G$ in the turbulence treatment to total $T G$ in the non-turbulence treatment

\begin{tabular}{|c|c|c|c|c|c|c|c|c|c|c|}
\hline \multirow[t]{2}{*}{ Parameter } & \multicolumn{2}{|c|}{$\operatorname{Stn} 1$} & \multicolumn{2}{|c|}{$\operatorname{Stn} 4$} & \multicolumn{2}{|c|}{$\operatorname{Stn} 7$} & \multicolumn{2}{|c|}{$\operatorname{Stn} 14$} & \multicolumn{2}{|c|}{ Lab } \\
\hline & Tur. & Non-tur. & Tur & Non-tur. & Tur. & Non-tur. & Tur. & Non-tur. & Tur. & Non-tur. \\
\hline$g(0-1)$ & 1.16 & 1.29 & 1.80 & 0.10 & 0.78 & 0.67 & 0.89 & 0.52 & 1.02 & 0.10 \\
\hline$a_{\{0-1\}}$ & 0.92 & 1.24 & 3.59 & 2.68 & 3.29 & 2.51 & 1.97 & 2.01 & -0.40 & 0.10 \\
\hline$T G_{(0-1)}$ & $1.44 \times 10^{6}$ & $1.77 \times 10^{6}$ & $8.32 \times 10^{5}$ & $3.16 \times 10^{4}$ & $2.63 \times 10^{5}$ & $1.49 \times 10^{5}$ & $1.99 \times 10^{6}$ & $1.09 \times 10^{6}$ & $4.47 \times 10^{6}$ & $5.99 \times 10^{5}$ \\
\hline$g_{(1-2)}$ & 2.95 & 0.30 & 1.86 & 0.13 & 1.96 & 0.39 & 0.70 & 0.06 & 1.65 & 0.36 \\
\hline$a_{\{1-2\}}$ & -1.24 & 0.87 & -0.65 & 0.86 & 0.02 & 1.36 & -1.29 & -1.51 & -1.75 & -0.47 \\
\hline$T G_{(1-2)}$ & $1.94 \times 10^{6}$ & $2.99 \times 10^{5}$ & $1.61 \times 10^{6}$ & $9.54 \times 10^{4}$ & $1.46 \times 10^{6}$ & $2.44 \times 10^{5}$ & $1.78 \times 10^{6}$ & $1.44 \times 10^{5}$ & $3.16 \times 10^{6}$ & $1.88 \times 10^{6}$ \\
\hline Total TG & $3.37 \times 10^{6}$ & $2.06 \times 10^{6}$ & $2.44 \times 10^{6}$ & $1.27 \times 10^{5}$ & $1.72 \times 10^{6}$ & $3.93 \times 10^{5}$ & $3.76 \times 10^{6}$ & $1.23 \times 10^{6}$ & $7.62 \times 10^{6}$ & $2.48 \times 10^{6}$ \\
\hline Ratio & & 63 & 19 & .2 & & .38 & & 06 & 3. & 07 \\
\hline
\end{tabular}

Table 3. Paraphysomonas imperforata. Ingestion rate (FLB flagellate ${ }^{-1} \mathrm{~h}^{-1}$ ), concentration (cells $\mathrm{ml}^{-1}$ ) and diameter ( $\mu \mathrm{m}$ ) in the laboratory experiment. Data are means $( \pm 1 \mathrm{SE})$ of 3 replicates. See text for regression used to obtain ingestion rates; $R^{2}>0.97$

\begin{tabular}{|c|c|c|c|c|c|c|}
\hline \multirow[t]{2}{*}{ Time $(h)$} & \multicolumn{3}{|c|}{ - Turbulence } & \multicolumn{3}{|c|}{$\longrightarrow$ No turbulence } \\
\hline & Ingestion rate & Concentration & Diameter & Ingestion rate & Concentration & Diameter \\
\hline 0 & $2.70(0.24)$ & $1070(42.8)$ & $10.2(0.21)$ & $2.11(0.29)$ & $1170(43.6)$ & $9.6(0.15)$ \\
\hline 24 & & $1850(1220)$ & $10.1(0.85)$ & & $772(60.5)$ & $10.3(0.05)$ \\
\hline 48 & & $5340(4530)$ & $8.4(0.29)$ & & $3180(195)$ & $10.4(0.32)$ \\
\hline
\end{tabular}

exponential (straight lines in the log plots of Fig. 3). Natural bacteria-sized particles, stained with DAPI, increased in the first $12 \mathrm{~h}$ of the experiment, and then tended to level-off or decrease to the end of the incubation.

Total bacteria consumed per unit water volume in the incubation period was always higher (1.6- to 19fold) in the turbulence treatment (Table 2). Specific

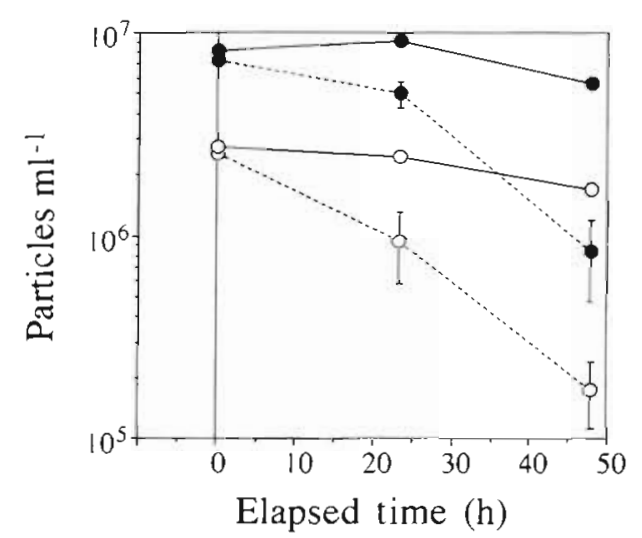

Fig. 4. Paraphysomonas umperforata. Laboratory grazing experiment. Symbols as in Fig. 3 apparent growth rates of bacteria were very similar in both treatments for the first $12 \mathrm{~h}$. Specific grazing rates were also similar with the exception of Stn 4 , where the turbulence treatment produced 18-fold higher grazing rates. After the initial $12 \mathrm{~h}$, grazing rates were 5 - to 14 fold higher in the turbulence treatment. Bacterial specific growth rates obtained by adding grazing rates and apparent growth rates were quite high, especially during the first $12 \mathrm{~h}$ (up to $5.39 \mathrm{~d}^{-1}$ in 1 case) and in general somewhat higher in the turbulence treatment (maximum of 1.94-fold higher).

In the laboratory experiment, turbulence had similar effects on the feeding of the chrysomonad Paraphysomonas imperforata (Fig. 4). In this case, however, live bacteria were strongly controlled by the grazing pressure exerted by the protozoan, especially in the turbulence treatment. In the non-turbulence treatment grazing was balanced by bacterial growth during the first $24 \mathrm{~h}$ and then there was a decline of bacterial concentration. The direct ingestion of FLB into protozoan food vacuoles, during the initial minutes of the experiment, was not significantly different between treatments ( $p=0.190)$, although there seemed to be a trend towards higher ingestion rates in the turbulence treatment (Table 3). 
Protozoa presented a growth rate of $0.80 \mathrm{~d}^{-1}$ in the turbulence treatment versus a growth rate of $0.50 \mathrm{~d}^{-1}$ for the non-turbulence treatment. Protozoan cell sizes were smaller in the turbulence treatment after $48 \mathrm{~h}$, although the variability was very high. This higher variability among the replicates of the turbulence treatment was a general trend in all experiments performed, independently of the choice of response variable one chose.

\section{DISCUSSION}

The results show a clear effect of turbulence on the microbial community that results in increased grazing on bacteria, but the mechanism underlying this trend remains unresolved. The turbulence level used in these experiments was high as compared to mid-ocean upper mixed layer conditions. The lower end of the range of energy dissipation rates in the beakers overlaps with the highest values measured in the ocean, but the average is higher than measured literature data (up to $5 \mathrm{~cm}^{2} \mathrm{~s}^{-3}$ in MacKenzie \& Leggett 1993), The levels of turbulence used in our experiments could probably be found under strong storm events and near the surface, but data are nonexistent for these conditions owing to logistical problems of field measurements. The few dissipation rate measurements available for similar biological experiments carried on in micro- and mesocosms were in the very high range of natural values as well $\left(0.05\right.$ to $0.15 \mathrm{~cm}^{2} \mathrm{~s}^{-3}$ in Marrasé et al. $1990 ; 0.07$ to $0.54 \mathrm{~cm}^{2} \mathrm{~s}^{-3}$ in Saiz \& Alcaraz $1992 \mathrm{~b}$; 2 to $38 \mathrm{~cm}^{2} \mathrm{~s}^{-3}$ in Howarth et al. 1993). Despite the span of 4 orders of magnitude in dissipation, the calculated Kolmogorov length microscale only ranges from 670 to $130 \mu \mathrm{m}$.

In our experiments, the length microscale was larger than $33 \mu \mathrm{m}$ (at the peak turbulence level) and averaged $150 \mu \mathrm{m}$, and eddies should not exist below these sizes. Most protozoa are smaller in size and should not have experienced the velocity fluctuations of eddy motion, although some large ciliates might have. Unless all the difference in grazing was caused by large protozoa, mechanisms other than eddy motion act to increase grazing rates below the microscale. Shimeta (1993) pointed out that organisms smaller than the turbulence microscale can have encounter rates with prey particles increased as a consequence of linear shear fields which depends directly on the energy dissipation rate.

Ingestion rates in the laboratory, using Paraphysomonas imperforata, were not statistically different between treatments. Shimeta et al. (1994), reported the same result with this organism, when they were testing the effect of linear shear fields (with Couette cylinders) on ingestion. They mentioned the importance of specific morphologies and feeding behaviors of individual species to explain why, in this case, ingestion would not be enhanced by the linear shear field. In our case, protozoa in the turbulence treatment were smaller and were more abundant at the end of the incubation. The higher grazing rates, observed from the decrease in tracer particles, means protozoa are probably dividing faster while maintaining their ingestion rate constant and as a result are getting smaller. This would argue against an enhancement of ingestion rates caused directly by turbulence but would point toward a behavioral or physiological response to turbulence which results in increased grazing. Unfortunately, no additional samples were taken for protozoan counting and sizing during field experiments to determine whether these changes can be generalized. Very similar results were observed of calanoid copepods (Saiz \& Alcaraz 1992a, Saiz et al. 1992). Copepods under turbulence showed a variety of physiological and behavioral changes such as an increase in excretion rates and a decrease in size. The result was that metabolic rates were higher and gross growth efficiency (GGE) was reduced. Analogous processes could be taking place with protozoa.

The increase in bacterial concentrations in the experiments in the Gulf of Mexico were not expected to occur, and are most likely the result of an enhancement of growth owing to water manipulation and experimental vessel wall effects. Similar increases have been reported before in bottle incubations and were regularly observed in this cruise in parallel experiments run for a different purpose (Wade Sheldon Jr pers. comm.). A further enhancement of bacterial growth could be caused by remaining dissolved nutrients carried over with the FLB tracer. This possibility is inferred by observation that the highest bacterial growth rates occurred at stations with the highest percentage of FLB added. Additionally, bacterial growth rates were higher in the turbulence treatment. This could be a direct effect of turbulence and the higher grazing rates would be a result of higher bacterial concentrations. However, some scattered evidence points toward a negative effect of turbulence on bacterial growth and metabolism (Toma et al. 1991, Möseneder \& Herndl 1994). An experiment run with bacteria $\left(10^{7} \mathrm{ml}^{-1}\right)$ and FLB $\left(3 \times 10^{6} \mathrm{ml}^{-1}\right)$ under the same experimental conditions as before showed no difference in bacterial growth between treatments (data not shown). Bacterial growth is most likely differentially fueled by the nutrients released from protozoan grazing. Higher grazing in the turbulence treatment would then result in higher bacterial growth rates.

A complicated picture of the physical effects of turbulence on the physiology and probably swimming 
and feeding behavior of protozoa has emerged from this study, even in a simplified setting with one model protozoan feeding on a single bacterial strain. Grazing is increased by turbulence in these microbial systems but is probably not the result of increased encounter probabilities with prey particles. Other aspects, such as the effect of different turbulence intensities or the intermittence of turbulence events on the microbial components of the food web are still open to question. This study shows the potential for small-scale turbulence as an important factor enhancing the control of bacterial numbers by microplanktonic grazing.

Theoretical estimations of the effects of small-scale turbulence on biological processes can be inaccurate because of the incomplete physical understanding we have in this field (Tennekes \& Lumley 1972, Nelkin 1992). It would be useful to directly visualize natural flow fields at the micrometer scale to ascertain whether protozoa directly experience some sort of uncorrelated velocity field which increases encounter rates with prey particles.

Acknowledgements. We thank Larry Pomeroy, Celia Marrasé, Mary Ann Moran, Peter Verity, and 2 anonymous reviewers for their comments on the manuscript, Charles Robertson for his help with the laser anemometer and the crew of the RV 'Pelican' for their help on board. This work was supported by NSF grant OCE 9115673 to L.R. Pomeroy, and NOAA Office of Sea Grant NA80AA-D00091.

\section{LITERATURE CITED}

Azam, F., Smith, D. C. (1991). Bacterial influence on the variability in the ocean's biogeochemical state: a mechanistic view. In: Demers, S. (ed.) Particle analysis in oceanography. NATO ASI Series, Vol. G 27. Springer-Verlag, Berlin, p. $214-236$

Bergh, Ø, Børsheim, K. Y., Bratbak, G., Heldal, M. (1989). High abundance of viruses found in aquatic environments. Nature 340: 467-468

Caron, D. A., Goldman, J. C., Dennett, M. R. (1986). Effect of temperature on growth, respiration, and nutrient regeneration by an omnivorous microflagellate. Appl. environ. Microbiol. 52: 1340-1347

Choi, J. W. (1994). Sources of imbalance between bacterial production and mortality in natural waters. Ph.D. dissertation, University of Georgia, Athens

Choi, J. W., Peters, F. (1992). Effects of temperature on two psychrophilic ecotypes of a heterotrophic nanoflagellate, Paraphysomonas imperforata. Appl. environ. Microbiol. 58: $593-599$

Fenchel, T. (1982). Ecology of heterotrophic microflageliates. II. Bioenergetics and growth. Mar. Ecol. Prog. Ser. 8: $225-231$

Fenchel, T. (1986). The ecology of heterotrophic microflagellates. Adv, Microb. Ecol. 9:57-97

Fenchel, T. (1987). Ecology of protozoa. Springer-Verlag, New York

Gerritsen, J., Strickler, J. R. (1977). Encounter probabilities and community structure in zooplankton: a mathematical model. J. Fish. Res. Bd Can. 34: 73-82
Gonzalez, J. M., Sherr, E. B., Sherr, B. F. (1990). Size-selective grazing on bacteria by natural assemblages of estuarine flagellates and ciliates. Appl. environ. Microbiol. 56: $583-589$

Howarth, R. W., Butler, T., Lunde, K., Swaney, D., Chu, C. H. (1993). Turbulence and planktonic nitrogen fixation: a mesocosm experiment. Limnol. Oceanogr. 38: 1696-1711

Mackenzie, B. R., Leggett, W. C. (1993). Wind-based models for estimating the dissipation rates of turbulent energy in aquatic environments: empirical comparisons. Mar. Ecol. Prag. Ser. 94: 207-216

Marrasé, C., Costello, J. H., Granata, T., Strickler, J. R. (1990). Grazing in a turbulent environment: energy dissipation, encounter rates, and efficacy of feeding currents in Centropages hamatus. Proc. natn. Acad. Sci. U.S.A. 87 : 1653-1657

Marrasé, C., Lim, E. L., Caron, D. A. (1992). Seasonal and daily changes in bacterivory in a coastal plankton community. Mar. Ecol. Prog. Ser. 82: 281-289

Monger, B. C., Landry, M. R. (1990). Direct-interception feeding by marine zooflagellates: the importance of surface and hydrodynamic forces. Mar. Ecol. Prog. Ser. 65: $123-140$

Monger, B. C., Landry, M. R. (1992). Size-selective grazing by heterotrophic nanoflagellates: an analysis using livestained bacteria and dual-beam flow cytometry. Arch. Hydrobiol. Beih. Ergeb. Limnol 37: 173-185

Möseneder, M. M., Herndl, G. J. (1994). Influence of turbulence on bacterial production in the sea. EOS Trans. Am. geophys. Un. 75 (Suppl.): $138-138$

Nelkin, M. (1992). In what sense is turbulence an unsolved problem? Science 255: 566-570

Pace, M. L., McManus, G. B., Findlay, S. E. G. (1990). Planktonic community structure determines the fate of bacterial production in a temperate lake. Limnol. Oceanogr. 35: 795-808

Peters, F. (1994a). Effects of small-scale turbulence on microplankton grazing rates. EOS Trans. Am. geophys. Un. 75 (Suppl.): 183-183

Peters, F. (1994b). Prediction of planktonic protistan grazing rates. Limnol. Oceanogr. 39: 195-206

Proctor, L. M., Fuhrman, J. A. (1990). Viral mortality of marine bacteria and cyanobacteria. Nature 343: 60-62

Rothschild, B. J., Osborn. T. R. (1988). Small-scale turbulence and plankton contact rates. J. Plankton Res. 10: $465-474$

Saiz, E., Alcaraz, M. (1992a). Enhanced excretion rates induced by small-scale turbulence in Acartia (Copepoda: Calanoida). J. Plankton Res. 14:681-689

Saiz, E., Alcaraz, M. (1992b). Free-swimming behaviour of Acartia clausi (Copepoda: Calanoida) under turbulent water movement. Mar. Ecol. Prog. Ser. 80: 229-236

Saiz, E., Alcaraz, M., Paffenhöfer, G.-A. (1992). Effects of small-scale turbulence on feeding rate and gross-growth efficiency of three Acartia species (Copepoda: Calanoida). J. Plankton Res. 14: 1085-1097

Salat, J., Marrasé, C. (1994). Exponential and linear estimations of grazing on bacteria: effects of changes in the proportion of marked cells. Mar. Ecol. Prog. Ser. 104: 205-209

Sherr, B. F., Sherr, E. B., Fallon, R. D. (1987). Use of monodispersed, fluorescently labeled bacteria to estimate in situ protozoan bacterivory. Appl. environ. Microbiol. 53: 958-965

Shimeta, J (1993). Diffusional encounter of submicrometer particles and small cells by suspension feeders. Limnol. Oceanogr. 38: 456-465

Shimeta, J., Jumars, P. A., Lessard, E. J. (1994). Influences of 
turbulence on feeding rates of planktonic protozoan suspension feeders. EOS Trans. Am. geophys. Un. 75 (Suppl.): $74-74$

Sundby, S., Fossum, P. (1990). Feeding conditions of Arctonorwegian cod larvae compared with the RothschildOsborn theory on small-scale turbulence and plankton contact rates. J. Plankton Res. 12: 1153-1162

Tennekes, H., Lumley, J. L. (1972). A first course in turbulence. MIT Press, Cambridge, MA

Toma, M. K., Ruklisha, M. P., Vanags, J. J., Zeltina, M. O.,

This article was presented by S. Y. Newell (Semor Editorial Advisor), Sapelo Island, Georgia, USA
Leite, M. P., Galinina, N. I., Viesturs, U. E., Tengerdy, R. P. (1991). Inhibition of microbial growth and metabolism by excess turbulence. Biotechnol. Bioeng. 38: 552-556

Verity, P. G. (1991). Feeding in planktonic protozoans: evidence for non-random acquisition of prey. J. Protozool. 38: $69-76$

Willams, P. J. leB. (1984). A review of measurements of respiration rates of marine populations. In: Hobbie, J. E., Williams, P. J. leB. (eds.) Heterotrophic activity in the sea. NATO, New York, p. 357-389

Manuscript first received: May 23, 1994 Revised version accepted: August 15, 1994 